\title{
The Comparative Politics of Colonialism and Its Legacies: An Introduction*
}

\author{
Alexander De Juan \\ GIGA German Institute of Global and Area Studies and the University of Konstanz
}

\section{Jan Henryk Pierskalla}

The Ohio State University

\begin{abstract}
What are the causes and consequences of colonial rule? This introduction to the special issue "Comparative Politics of Colonialism and Its Legacies" surveys recent literature in political science, sociology, and economics that addresses colonial state building and colonial legacies. Past research has made important contributions to our understanding of colonialism's long-term effects on political, social, and economic development. Existing work emphasizes the role of critical junctures and institutions in understanding the transmission of those effects to present-day outcomes and embraces the idea of design-based inference for empirical analysis. The four articles of this special issue add to existing research but also represent new research trends: increased attention to (I) the internal dynamics of colonial intervention; (2) noninstitutional transmission mechanisms; (3) the role of context conditions at times of colonial intervention; and (4) a finer-grained disaggregation of outcomes, explanatory factors, and units of analysis.
\end{abstract}

\section{Keywords}

colonialism, historical legacies, economic development, democratization, state building

\footnotetext{
Corresponding Author:

Jan Henryk Pierskalla, Department of Political Science, The Ohio State University, 2147 Derby Hall, 154 $\mathrm{N}$ Oval Mall, Columbus, $\mathrm{OH} 43210$, USA.

Email: pierskalla.4@osu.edu

*This special issue of Politics \& Society titled "The Comparative Politics of Colonialism and Its Legacies" features an introduction and four papers that were presented as part of a workshop held at The Ohio State University, April 2016, organized by Marcus Kurtz and Jan Henryk Pierskalla.
} 
Colonialism and its legacies have always been topics of intense scholarly discourse within the field of history. Recently they have gained prominence as topics of inquiry in the social sciences, as well. Political scientists, economists, and sociologists are adding their insights and techniques to the exploration of the political, economic, and sociological ramifications of colonial rule, especially Western colonial rule, with fruitful results. ${ }^{1}$

Heightened interest in the study of colonialism is related to a more general desire to explain differences among countries in areas such as economic development, the quality of democracy, and levels of state capacity and to find "fundamental" instead of merely "proximate" causes for those differences. ${ }^{2}$ Colonialism emerges as a prime candidate for a "fundamental cause" because it is often understood as a "critical juncture." ${ }^{\prime 3}$ Although societies affected by colonial rule certainly had important precolonial political, economic, and social institutions, the sheer scale and violence of the transformation introduced by colonial rule makes it a useful point of origin for understanding the political economies of the developing world today.

The desire to identify fundamental causes coincides with the recent "credibility revolution" in empirical social science. ${ }^{4}$ Increased pressure to offer evidence for narrow causal effects has changed the types of research designs employed in economics, political science, and sociology. The study of colonialism is a fertile ground for new types of design-based inference, because idiosyncratic circumstances - such as geographic conditions or decisions by colonial administrators - can be exploited as natural experiments. ${ }^{5}$

Before we highlight recent trends in research on colonialism and colonial legacies, we briefly summarize in the following sections some key findings of research on the long-term consequences of colonialism for the interrelated economic and political development of former colonies.

\section{Colonial Legacies and Economic Development}

Perhaps best known is the growing body of work that identifies colonial rule as a driver of dramatically divergent income levels across countries following the Industrial Revolution. In particular, it has been argued that differences between types of colonial rule explain the variation in income levels across the developing world. ${ }^{6}$ In its most prominent formulation, by Acemoglu, Johnson, and Robinson, ${ }^{7}$ the argument is that differences in colonial rule were induced by variation in local geographic endowments and disease burdens. ${ }^{8}$ Some territories became settler colonies with institutions that protected private property and (eventually) offered the possibility of civil liberties and political participation for larger parts of the (nonindigenous) population. These populations were able to reap the benefits of private property protection and limits to government extraction, which facilitate innovation and growth. ${ }^{9}$ Others became extractive colonies with an institutional framework that enabled a small European elite to monopolize political and economic power. This monopoly established a framework for predatory rule that remained in place even after independence and typically produced an autocracy with a dismal record of economic development. The consequence 
was a "reversal of fortune," by which the most developed non-Western societies were saddled with extractive institutions after being colonized, whereas areas less attractive to colonial regimes at the time of colonization, such as North America, Australia, and New Zealand, benefited in the long term. ${ }^{10}$

Other institutionalist arguments have pointed to the legacy effects of legal systems introduced by colonial rule or the distinction between direct and indirect rule. Colonies subject to British rule inherited versions of British common law with stronger protections for the property of private investors. In contrast, colonies under Spanish, Portuguese, or French rule adopted a legal system influenced by Roman civil law traditions, which hampered economic development in the long run. ${ }^{11}$ Similarly, indirect rule, often associated with the British, has typically been seen as having positive (or, at a minimum, less negative) consequences for economic development, ${ }^{12}$ although some evidence from India suggests that direct British rule was actually more beneficial for local welfare. ${ }^{13}$

\section{Colonial Legacies and Political Development}

Other studies pay more attention to the effects of colonial rule on state building and state capacity. Classically, Jeffrey Herbst ${ }^{14}$ has argued that colonial rule in Africa did little to establish effective rule, in large part because of the difficulty of governing the vast colonial territories. That difficulty led to states that were barely able to extend their reach beyond capital or coastal cities. Young, in turn, sees the African colonial state as very transformative (a "crusher of rocks"). ${ }^{15}$ Moreover, colonial rule in Africa established "artificial states," putting various ethnic groups into political unions without the necessary glue of, for example, a national identity. ${ }^{16}$ In contrast, Atul Kohli has argued that Japanese colonial rule in Korea was hugely important to the creation of an effective and capable state. ${ }^{17}$ The idea that Japanese colonial rule was a catalyst of state development has been put also forward in the context of China, ${ }^{18}$ where colonial rule either introduced or reinforced bureaucratic traditions conducive to effective governance. Apart from bureaucratic legacies, the enduring presence of colonial infrastructure (e.g., roads) is another other way colonial rule might have helped to build state capacity in the long term. ${ }^{19}$ In the region of Latin America, however, the effects of colonial rule on the long-term development of state capacity have been seen as ephemeral. ${ }^{20}$

Going beyond state building and state capacity, researchers have also looked at the quality of institutions. Mahmood Mamdani's classic Citizen and Subject eloquently and forcefully makes the case that colonial rule created institutional legacies that led to the rise of African despots. ${ }^{21}$ Others have argued that British colonial rule brought with it some exposure to and experience with parliamentary rule that helped former British colonies to consolidate democratic regimes, ${ }^{22}$ although indirect British rule might also be associated with despotism. ${ }^{23}$ The institutional legacy of British rule was conditional on the preexisting level of political centralization. Hariri argues that colonies with few or no centralized forms of government before colonization were most exposed to European institutional forms of government and experienced the most beneficial 
long-term effects. ${ }^{24}$ Societies with preexisting hierarchical structures experienced the usurpation of their traditional institutions by European colonizing powers without the substitution of European forms of (semi-) participatory government.

Sociologists have identified the key role of Christian missionaries, in particular Protestant missionaries, in generating a democratic legacy for many former colonies, through the spread of literacy, mass printing, and voluntary organizations. ${ }^{25}$ Although contact with Christian missionaries might have had beneficial long-term effects for human capital, political participation, and eventually democratization, contact with the colonial slave trade has had pernicious effects on individual-level trust in Western Africa. ${ }^{26}$

Political legacies of colonialism include political instability, violence, and ethnic exclusion. The frequent partitioning of preexisting ethnic groups by colonial regimes, especially in Africa, created lasting effects for ethnic politics. ${ }^{27}$ Such partitioning can be linked to civil war. ${ }^{28}$ Similarly, the degree to which colonial rule included or excluded ethnic minorities can also tied to the prevalence of civil strife. ${ }^{29}$

\section{Recent Trends in the Study of Colonialism and Colonial Legacies}

We think the preceding sections offer a fair, if selective, description of empirically focused research on colonialism in the last twenty years. The articles of this special issue directly speak to that research. More important, the articles also nicely reflect new points of emphasis in the literature and allow us to describe some contours of research to come. We identify four important recent trends that should characterize future research in this field: (1) attention to the internal dynamics of colonial rule; (2) noninstitutional interventions and transmission mechanisms; (3) the role of contextual conditions in shaping the types and consequences of colonial rule; and (4) the increased disaggregation of outcomes, explanatory variables, and units of analysis.

\section{Dynamics of Colonial Interventions}

Previous research on colonial state building has been interested primarily in the longterm repercussions, rather than in the dynamics, of the colonial interventions themselves. The colonial period has been described as a "critical juncture that has placed the respective country's social, economic and political development on specific trajectories. ${ }^{30}$ Consequently, research has focused on identifying the characteristics of colonial regimes that may have exerted such long-term influences-for example, the density of colonial settlers, ${ }^{31}$ forms of direct and indirect governance, ${ }^{32}$ strategies of economic extraction,,$^{33}$ and economic investment. ${ }^{34}$ Such characteristics are often explained with reference to specific structural antecedent conditions shaping rational state building strategies of colonial states..$^{35}$

A focus on preexisting structural conditions in explaining variation in colonial interventions tends to lead to an underestimation of the dynamic character of the colonial state-building process. Local context conditions change over time as a consequence, for 
example, of the discovery of natural resources, reconfigurations of ethnic institutions, or climatic variations. Such changes call for adaptations of colonial state-building strategies. Moreover, within the framework of given structural conditions, colonial agents and administrations play an influential role in shaping colonial policies. In particular, the early phase of colonization constituted a moment of relatively free choice, where "willful actors shape outcomes." 36 Decision making under incomplete information, principal-agent problems, and limited human and institutional capacities shaped the colonial state-building process and often led to mismatches between observable structural preconditions and actual colonial policies.

Engaging in more detailed analyses of the processes of colonial state building rather than just their long-term repercussions - is promising from at least two perspectives. First, the processes help us to understand variations in colonial interventions as well as long-term effects. Second, they give insights into more general dynamics that can inform analyses of contemporary state building. It is against this background that recent studies work to shed new light on the internal dynamics of colonial state building. $\mathrm{Xu}$, for example, investigates bureaucratic dynamics within the British colonial administration of the late colonial period (1854-1966). He finds strong effects of patronage politics on staff allocation and promotion, with detrimental long-term effects on former colonies' fiscal capacity. ${ }^{37}$ Guardado, also investigating personnel issues of colonial administrations, traces the effects of patronage politics within the Spanish colonial empire on colonial governance. ${ }^{38}$ De Juan analyzes associations between strategies of colonial extraction and anticolonial resistance in the former colony of German East Africa. He finds that the geographical expansion of extractive activities rather than the intensification of extraction in areas under state control was a key driver of rebellion. ${ }^{39}$ A related study of German East Africa demonstrates how lack of reliable information and dynamic strategic decision making shaped the process of territorial expansion of the colonial state. ${ }^{40}$

Two articles in this special issue push farther along those lines. Lee links the international position of colonial powers to their strategies of expansion in colonial territories. ${ }^{41} \mathrm{He}$ finds the British Empire's successive expansion in South Asia was dramatically shaped by wars in Europe. British colonial decision makers were much less likely to establish forms of indirect rule with precolonial elites in India when administrative and military resources of the British Empire where concentrated elsewhere. On the other hand, in peacetime, British expansion across the Indian subcontinent was more likely to feature arrangements of indirect rule. Such variation of engagement within a colonial regime had important long-term consequences for the power and influence of high-level castes in India, which were either coopted or excluded from administrative power depending on when they were subjugated by the British. This is an important example of how internal dynamics within the British Empire shaped colonial strategies on the ground.

De Juan, Krautwald, and Pierskalla also shine a light on internal dynamics of colonial state building. Their case study is the creation of a police force in the colony of German Southwest Africa - modern day Namibia - in the aftermath of the Nama and Herero genocide..$^{42}$ They show how macro-strategic goals of territorial control, 
resource extraction, and protection of white settlers shaped the territorial expansion of police stations, reflecting the political priorities of colonial administrators and settlers alike. At the same time, the analysis shows that territorial expansion of coercive state presence faced an immense challenge of personnel recruitment. Finding, recruiting, and overseeing qualified personnel in remote police stations located in politically and economically important areas created substantial principal-agent problems. Drawing on detailed individual-level archival data on police officers, they document the internal dynamics of colonial personnel management and highlight the impact of internal bureaucratic challenges on colonial governance and patterns of colonial state building.

\section{Noninstitutional Interventions and Channels of Transmission}

Most previous research has stressed the role of colonial institutions as well as of institutional channels of long-term transmission. The general underlying idea has its roots in a rational-choice perspective of institution building: institutions are created to serve the interests of actors and represent a stable equilibrium. Consequently, institutions persist as long as either a majority of individuals and groups or particularly influential elites see the costs of leaving the equilibrium as higher as the potential benefits. ${ }^{43}$ Power-holding elites are often unwilling to accept institutional change simply because winners by such change cannot credibly commit to compensating the losing elite. ${ }^{44}$ Moreover, power-holding elites may be able to sustain institutional arrangements when they lose their formal positions by tapping on informal resources of power. ${ }^{45}$ Consequently, once institutions are socially and politically "locked-in," even longterm institutional change is unlikely without any substantive exogenous shock. ${ }^{46}$

Although this perspective provides a compelling argument about the long-term repercussions of colonial state building, it describes only one among various other potential channels of transmission. The footprints of colonial state building extend beyond the establishment of specific institutions. Colonial interventions often exerted substantive and long-lasting effects on social and economic conditions. For example, projects of colonial education and "civilization" as well as proselytizing missionary activities may have influenced norms that were then transmitted from generation to generation: "The young are enculturated by the previous generation, while they in turn enculturate the next generation." 47 Similarly, specific forms of colonial economic intervention may have had long-lasting effects on economic organization: for example, forcefully concentrating agricultural production on specific crops, introducing specific modes of production, or establishing specific patterns of international trade. These in turn may shape longer-term economic trajectories through, for example, economies of scale or technological progress.

Complementing existing work on colonial institutions and institutional channels of long-term transmission can lead to a fuller understanding of the myriad ways colonial interventions have influenced social, economic, and political trajectories. As referenced above, research on colonial missionary education illuminates substantive legacies of human capital that affect political development and democracy. ${ }^{48}$ In related 
research, Cagé and Rueda find that proximity to a printing press in nineteenth-century Africa is associated with higher levels of present-day social capital. The authors highlight the role of demand-side mechanisms as a potential channel: the early availability of printing technology enabled the local development of a culture of writing and information diffusion that still persists. ${ }^{49}$ Research on colonial schools in Benin finds strong effects on standards of living, occupational choices, and political participation for the first cohorts of colonial school attendees and their descendants, and even spillover effects to co-villagers..$^{50}$ Outside the realm of missionaries and schooling, Gaikwad investigates India and finds that European trading companies, by drawing local economies into networks of long-distance maritime trade, played a key role in the enduring transformation of geographical and social patterns of economic organization. ${ }^{51}$ It seems clear that the roots of long-term economic transformation pre-date the colonial administration of India and were driven not by formal institutional actions but by economic change. Overall, this research strongly suggests that we must take noninstitutional channels of transmission seriously when assessing the long-term effects of colonialism. ${ }^{52}$

In this special issue, Montgomery advances the literature on colonial legacies of Christian missionaries..$^{53}$ Although a substantial body of work has already documented the general benefits of Christian missionary activity on human capital development, he looks at the extent to which exposure to missionary schooling affected gender inequality in educational attainment in the long term. Using detailed school-level information from colonial Tanzania and geographically referenced modern-day outcome measures of educational attainment, he shows that both Catholic and Protestant missionaries had positive effects on educational attainment. When the data are disaggregated by gender, however, Catholic schools generate positive but significantly smaller effects on female educational attainment. This difference in effect has contributed to gender inequality in Tanzania, despite overall gains in educational attainment. This study shows that human capital and social norms can play an important role for long-term effects, independent of institutional legacies: Christian missionaries not only changed human capital accumulation, but also spread particular ideas about the appropriate roles of men and women that shaped gender politics for decades after colonial rule.

\section{Conditions at Times of Colonial Intervention}

The contexts of colonization varied greatly across colonies and across colonizing states. Early colonial encounters in the Americas of the fifteenth century had little in common with colonization in Africa during the age of the "New Imperialism." Colonial projects differed, most notably, in the objectives of the metropolitan states, in the resources invested into colonial efforts, and in the international state systems in which processes of colonial conquest were embedded. Such different conditions were also likely translated into different characteristics and dynamics of colonial state-building projects.

Thus, for example, Ola Olsson argues that the very heterogeneous era of colonization should actually be divided into different waves with distinct characteristics. In 
particular, he suggests more careful differentiation of an early "mercantilist" wave and a much later "imperialist" wave. In fact, his cross-country analysis reveals that positive effects of colonial duration on present-day levels of democracy are primarily driven by colonial interventions that took place during the imperialist wave. ${ }^{54}$ Mahoney's influential book investigating legacies of Latin American colonialism emphasizes how colonization efforts interacted with the political economies of the colonizers to produce vastly different long-term outcomes. ${ }^{55}$ Focusing on subnational dynamics of colonial state building, Pierskalla, De Juan, and Montgomery show how the specific context of the German colonial project translated into specific strategies of institution building that differed from what we know about French and British colonial efforts. As a latecomer to the "scramble for Africa," Germany's main interest—namely, positioning itself as a global imperial state - translated into the primary objective of securing its colonies and preventing any disturbances that might be interpreted as a sign of weakness by its international rivals. Using the case of the former colony of German East Africa, Pierskalla, De Juan, and Montgomery show that this context produced a specific approach to colonial state building. In that context, the state's efforts were driven by its imperative to secure order rather than to maximize extraction. ${ }^{56}$

An emerging issue in the literature is the role of precolonial political centralization and statehood. Several authors have identified the long-term effects of precolonial centralization on long-term development and called into question the transformative role of colonialism..$^{57}$ Specifically engaging the notion of a reversal of fortunes, ${ }^{58}$ Foa in this special issue offers an integrative approach; ${ }^{59}$ he argues that there exists a threshold effect for which political centralization and a history of statehood led to the avoidance of the imposition of extractive colonial institutions. The most advanced non-European states were able to fend off European colonization (or at least to minimize its influence). In fact, the threat of colonization led to "defensive modernization," whereas societies with moderate levels of statehood were attractive targets for colonial exploitation and suffered long-term economic stagnation. These findings show how important it is to consider the exact circumstances of colonization, including the timing, type of colonizer, and precolonial conditions, when trying to theorize or empirically evaluate colonial legacies.

\section{Careful Disaggregation}

Building on influential cross-country analyses of the long-term repercussions of colonial state building, recent research has adopted a finer-grained approach to individual countries and subnational regions. ${ }^{60}$ The turn to geographical disaggregation permits more context-specific analysis, micro-level investigation of specific causal mechanisms, and the use of more persuasive data and measurements. Disaggregating even further in terms of specific explanatory and outcome variables could further strengthen research into the dynamics and consequences of colonial state building.

Research into colonialism's long-term legacies has often tried to explain the effects of all colonial interventions, rather than to investigate individual periods. Periods of colonialism often lasted more than 100 years, over which there were pronounced 
differences in the objectives, intensity, and strategy of the colonial projects. The early stages of colonization, for example, may have been particularly relevant in shaping subsequent developments. ${ }^{61}$ State institutions had to be designed and established where there were no prior institutions of a similar kind. Because of their sunk costs, early colonial state-building processes are likely to have produced strong path dependencies that shaped subsequent state building. On the other hand, late colonial interventions may have been more consequential in influencing postcolonial developments, if we consider that colonial interventions often increased substantially in the scope of their policies as resources at their disposal increased.

On the subject of individual policies, a great deal of research has focused on extractive state activities. ${ }^{62}$ Extending investigations to other types of interventions promises important insights into new facets of colonial state building and their long-term implications. As an example, Jedwab, Kerby, and Moradi assess the long-term consequences and transmission channels of colonial spatial structuring. In particular, they investigate the repercussions of colonial railway construction for the internal organization of the colony. Postcolonial shocks dissipate the immediate effects of the initial colonial interventions, without, however, reversing the spatial equilibrium created by colonial infrastructural interventions. ${ }^{63}$ Focusing on the Christian reconquest of the Iberian Peninsula from Muslim control and colonization, Oto-Peralías and Romero-Ávila show that high rates of Christian frontier expansion put high degrees of power and leverage in the hands of individual elites, with negative effects on long-term development of their respective regions. ${ }^{64}$

It is likely that the repercussions of colonial interventions extend to a variety of other social and political developments. Thus, for example, Schmitt analyzes the potential associations between colonial heritage and the adoption and form of social security programs in former Spanish, French, and British colonies. ${ }^{65}$ Ali and colleagues use survey data to compare the salience of individual ethnic identities in former British and French colonies. In particular, they find evidence that the British "divide-and-rule" strategy had long-term effects on patterns of ethnic identification, such that survey respondents in Anglophone countries, as compared to respondents in Francophone countries, attached greater importance to specific ethnic identities than to a shared national identity. ${ }^{66}$ Pepinsky in turn uses disaggregated data from colonial censuses to look at the long-term effects of colonial ethnic migration on the quality of economic governance in Java. ${ }^{67}$

All four papers in this special issue are also instructive examples of the immense value of careful disaggregation to the study of colonialism and colonial legacies. Lee disaggregates the timing and international context of colonial interventions, to reveal pronounced differences in terms of immediate and long-term consequences of colonial conquests. Montgomery adds to our understanding of the long-term social effects of missionary activities in colonial times by drawing on detailed colonial records to disaggregate the role of missionary schooling. De Juan, Krautwald, and Pierskalla analyze patterns of colonial state building on two different, highly disaggregated, levels (grid cells and individuals) and discover mismatches between the patterns of spatial allocation of police stations and of individual personnel. Finally, Foa demonstrates 
that focusing on the direct effects of specific types of interventions may lead to faulty conclusions: the fact that colonial efforts interacted with preexisting local conditions resulted in different outcomes for similar types of interventions. All four papers highlight the need for a more careful consideration of the specificities of the local contexts of colonial interventions and for the conceptual disaggregation of dependent variables, explanatory factors, and units of analysis.

\section{Declaration of Conflicting Interests}

The author(s) declared no potential conflicts of interest with respect to the research, authorship, and/or publication of this article.

\section{Funding}

The author(s) received no financial support for the research, authorship, and/or publication of this article.

\section{Notes}

1. Two examples of the prominence attained by research on colonialism in the last twenty years: Daron Acemoglu, Simon Johnson, and James Robinson's "The Colonial Origins of Comparative Development: An Empirical Investigation" American Economic Review 91, no. 5 (2000): 1369-1401 has garnered more than 9800 cites, and Mahmood Mamdani's Citizen and Subject: Contemporary Africa and the Legacy of Late Colonialism (Princeton, NJ: Princeton University Press 1996), more than 5700 cites on Google Scholar.

2. Acemoglu, Daron, Simon Johnson, and James Robinson, "Institutions as the Fundamental Cause of Long-Run Growth," Handbook of Economic Growth, Philippe Aghion and Stephen Durlauf, eds. (Amsterdam: Elsevier North Holland, 2005).

3. Giovanni Capoccia and R. Daniel Kelemen, "The Study of Critical Junctures: Theory, Narrative, and Counterfactuals in Historical Institutionalism," World Politics 59, no. 3 (April 2007): 342.

4. Joshua D. Angrist and Jörn-Steffen Pischke, "The Credibility Revolution in Empirical Economics: How Better Research Design Is Taking the Con out of Econometrics," Journal of Economic Perspectives 24, no. 2 (2010): 3-30.

5. E.g., Acemoglu, Johnson, and Robinson, "The Colonial Origins of Comparative Development," use variation in settler mortality for an instrumental variable strategy; whereas James Feyrer and Bruce Sacerdote, "Colonialism and Modern Income: Islands as Natural Experiments," Review of Economics \& Statistics 91, no. 2 (2009): 245-62, exploit variation in wind strength to implement an instrumental variable estimation for the effects of the length of colonial rule.

6. For an overview, see Nathan Nunn, "The Importance of History for Economic Development," Annual Review of Economics 1 (2009): 65-92.

7. Acemoglu, Johnson, and Robinson, "The Colonial Origins of Comparative Development."

8. Ibid. Closely related is work by Engerman and Sokoloff on the role of geographic endowments for shaping economic colonial institutions in the Americas; Stanley Engerman and Kenneth Sokoloff, "Factor Endowments, Inequality, and Paths of Development among New World Economies," NBER Working Paper no. 9259 (Cambridge, MA: NBER, October 2002). 
9. This argument largely follows Douglass North, Institutions, Institutional Change and Economic Performance (New York: Cambridge University Press 1990).

10. Daron Acemoglu, Simon Johnson, and James Robinson, "Reversal of Fortune: Geography and Institutions in the Making of the Modern World Income Distribution," Quarterly Journal of Economics 117 (2002): 1231-94.

11. Rafael La Porta, Florencio Lopez-De-Silanes, and Andrei Shleifer, "The Economic Consequences of Legal Origins," Journal of Economic Literature 46, no. 2 (2008): 285-332.

12. Matthew Lange, "British colonial legacies and political development," World Development 32 (2004): 905-22.

13. Lakshmi Iyer, "Direct versus Indirect Colonial Rule in India: Long-Term Consequences," Review of Economics \& Statistics 92, no. 4 (2010): 693-713.

14. Jeffrey Herbst, States and Power in Africa: Comparative Lessons in Authority and Control (Princeton, NJ: Princeton University Press, 2000).

15. Crawford Young The African Colonial State in Comparative Perspective (New Haven, CT: Yale University Press, 1994).

16. Alberto Alesina, William Easterly, and Janina Matuszeski, “Artificial States," Journal of the European Economic Association 9, no. 2 (2011): 246-77.

17. Atul Kohli, State-Directed Development: Political Power and Industrialization in the Global Periphery (New York: Cambridge University Press, 2004).

18. Daniel C. Mattingly, "Colonial Legacies and State Institutions in China: Evidence from a Natural Experiment," Comparative Political Studies 50, no. 4 (2017): 434-63.

19. Daron Acemoglu, Camilo García-Jimeno, and James A. Robinson, "State Capacity and Economic Development: A Network Approach,” American Economic Review 105, no. 8 (2015): 2364-409.

20. Hiller Soifer, State Building in Latin America (New York: Cambridge University Press, 2016); Marcus Kurtz, Latin American State Building in Comparative Perspective: Social Foundations of Institutional Order (New York: Cambridge University Press, 2013), also argues that Latin America's colonial backwaters developed the strongest states, while colonial centers of power have much weaker records of state development.

21. Mamdani, Citizen and Subject.

22. Ola Olsson, "On the Democratic Legacy of Colonialism," Journal of Comparative Economics 37 (2009): 534-51.

23. Matthew Lange, Lineages of Despotism and Development: British Colonialism and State Power (Chicago: University of Chicago Press, 2009).

24. Jacob Gerner Hariri, "The Autocratic Legacy of Early Statehood," American Political Science Review 106, no. 3 (2012): 471-94.

25. Robert Woodberry, "The Missionary Roots of Liberal Democracy," American Political Science Review 106, no. 2 (2012); Tomila Lankina and Lullit Getachew, "Mission or Empire, Word or Sword? The Human Capital Legacy in Postcolonial Democratic Development," American Journal of Political Science 56, no. 2 (2012): 465-83.

26. Nathan Nunn and Leonard Wantchekon, "The Slave Trade and the Origins of Mistrust in Africa," American Economic Review 101, no. 7 (2011): 3221-52.

27. Daniel Posner, "The Colonial Origins of Ethnic Cleavages: The Case of Linguistic Divisions in Zambia," Comparative Politics 35 (2003): 127-46.

28. Stelios Michalopoulos and Elias Papaioannou, "The Long-Run Effects of the Scramble for Africa," American Economic Review 106, no. 7 (2016): 1802-48. 
29. Julian Wucherpfennig, Philipp Hunziker, and Lars-Erik Cederman, "Who Inherits the State? Colonial Rule and Post-Colonial Conflict," American Journal of Political Science 60, no. 4 (2016): 882-98.

30. James Mahoney, Colonialism and Postcolonial Development: Spanish America in Comparative Perspective (Cambridge University Press, 2010); Ruth Berins Collier and David Collier, Shaping the Political Arena: Critical Junctures, the Labor Movement, and Regime Dynamics in Latin America (Notre Dame, IN: University of Notre Dame Press, 2002).

31. Acemoglu, Johnson, and Robinson, "The Colonial Origins of Comparative Development."

32. Iyer, "Direct versus Indirect Colonial Rule in India."

33. Melissa Dell, "The Persistent Effects of Peru's Mining Mita," Econometrica 78, no. 6 (2010): 1863-1903.

34. Elise Huillery, "History Matters: The Long-Term Impact of Colonial Public Investments in French West Africa," American Economic Journal: Applied Economics 1, no. 2 (2009): 176-215.

35. Capoccia and Kelemen, "The Study of Critical Junctures."

36. Mahoney, Colonialism and Postcolonial Development.

37. Guo $\mathrm{Xu}$, The Costs of Patronage: Evidence from the British Empire (Job Market Paper, London School of Economics, 2017); online at http://www.lse.ac.uk/economics/ PhDjobMarket/jobMarketCandidates/GuoXu.aspx.

38. Jenny Guardado, Office-Selling and Long-Term Development in Peru (working paper, Georgetown University, July 2016).

39. Alexander De Juan, "Extraction and Violent Resistance in the Early Phases of State Building: Quantitative Evidence from the 'Maji Maji' Rebellion, 1905-1907,' Comparative Political Studies 49, no. 3 (2016): 291-323.

40. Jan Pierskalla, Alexander De Juan, and Max Montgomery, "The Territorial Expansion of the Colonial State: Evidence from German East Africa 1890-1909," British Journal of Political Science (forthcoming 2017).

41. Alexander Lee, "Redistributive Colonialism: The Long Term Legacy of International Conflict in India," Politics \& Society 45, no. 2 (2017): 173-224.

42. Alexander De Juan, Fabian Krautwald, and Jan Henryk Pierskalla, "Constructing the State: Macro Strategies, Micro Incentives, and the Creation of Police Forces in Colonial Namibia," Politics \& Society, 45, no. 2 (2017): 269-299.

43. Peter A. Hall and Rosemary C.R. Taylor, "Political Science and the Three New Institutionalisms," Political Studies 44, no. 5 (1996): 936-57; James Mahoney, "Path Dependence in Historical Sociology," Theory \& Society 29, no. 4 (2000): 507-48.

44. Acemoglu, Johnson, and Robinson, "The Colonial Origins of Comparative Development."

45. Daron Acemoglu and James A. Robinson, Economic Origins of Dictatorship and Democracy (Cambridge: Cambridge University Press, 2006).

46. Christoph Knill and Andrea Lenschow, “'Seek and Ye Shall Find!' Linking Different Perspectives on Institutional Change," Comparative Political Studies 34, no. 2 (2001): 187-215; B. Guy Peters, Jon Pierre, and Desmond S. King, "The Politics of Path Dependency: Political Conflict in Historical Institutionalism," Journal of Politics 67, no. 4 (2005): 1275-1300.

47. Lynne G. Zucker, "The Role of Institutionalization in Cultural Persistence," American Sociological Review 42, no. 5 (1977): 728.

48. Ibid. 
49. Julia Cagé and Valeria Rueda, "The Long-Term Effects of the Printing Press in SubSaharan Africa," American Economic Journal: Applied Economics 8, no. 3 (2016): 69-99.

50. Leonard Wantchekon, Marko Klašnja, and Natalija Novta, "Education and Human Capital Externalities: Evidence from Colonial Benin," Quarterly Journal of Economics 130, no. 2 (2015): 703-57.

51. Nikhar Gaikwad, East India Companies and Long-Term Economic Change in India (working paper, Yale University, 2015); online at https://ncgg.princeton.edu/IPES/2014/papers/ F1130_rm3.pdf.

52. See Nathan Nunn, "Culture and the Historical Process," Economic History of Developing Regions 27, no. 1 (2012): 108-26, for a more general discussion.

53. Max Montgomery, "Colonial Legacy of Gender Inequality: Christian Missionaries in German East Africa," Politics \& Society 45, no. 2 (2017): 225-268.

54. Olsson, "On the Democratic Legacy of Colonialism."

55. Mahoney, Colonialism and Post-Colonial Development.

56. Pierskalla, De Juan, and Montgomery, "The Territorial Expansion of the Colonial State."

57. Stelios Michalopoulos and Elias Papaioannou, "Pre-Colonial Ethnic Institutions and Contemporary African Development," Econometrica 81, no. 1 (2013): 113-52; Sanghamitra Bandhyopadhyay and Elliot Green, "The Reversal of Fortune Thesis Reconsidered," Journal of Development Studies 48, no. 7 (2012): 817-31.

58. Acemoglu, Johnson, and Robinson, "Reversal of Fortune."

59. Roberto Stefan Foa, "Persistence or Reversal of Fortune? Early State Inheritance and the Legacies of Colonial Rule," Politics \& Society 45, no. 2 (2017): 301-324.

60. See, e.g., Miriam Bruhn and Francisco A. Gallego, "Good, Bad, and Ugly Colonial Activities: Do They Matter for Economic Development?," Review of Economics \& Statistics 94, no. 2 (2011): 433-61; Dell, "The Persistent Effects of Peru's Mining Mita"; Rasmus Broms, "Colonial Revenue Extraction and Modern Day Government Quality in the British Empire," World Development 90 (2017): 269-80.

61. James Mahoney, The Legacies of Liberalism: Path Dependence and Political Regimes in Central America (Baltimore: Johns Hopkins University Press, 2001), 7; see also Hillel David Soifer, "The Causal Logic of Critical Junctures," Comparative Political Studies 45, no. 12 (2012): 1572-97.

62. Bruhn and Gallego, "Good, Bad, and Ugly Colonial Activities"; Abhijit Banerjee and Lakshmi Iyer, "History, Institutions, and Economic Performance: The Legacy of Colonial Land Tenure Systems in India," American Economic Review 95, no. 4 (2005): 1190-213.

63. Remi Jedwab, Edward Kerby, and Alexander Moradi, "History, Path Dependence and Development: Evidence from Colonial Railways, Settlers and Cities in Kenya," Economic Journal (January 2017); online at http://onlinelibrary.wiley.com/doi/10.1111/ecoj.12347/ abstract.

64. Daniel Oto-Peralías and Diego Romero-Ávila, "The Economic Consequences of the Spanish Reconquest: The Long-Term Effects of Medieval Conquest and Colonization," Journal of Economic Growth 21, no. 4 (2016): 409-64.

65. Carina Schmitt, "Social Security Development and the Colonial Legacy," World Development 70 (2015): 332-42.

66. Merima Ali, Odd-Helge Fjeldstad, Boqian Jiang, and Abdulaziz B. Shifa, Colonial Legacy, State Building and the Salience of Ethnicity in Sub-Saharan Africa, CMI Working Paper WP 2015:16 (Bergen: Chr. Michelsen Institute, 2015).

67. Thomas B. Pepinsky, "Colonial Migration and the Origins of Governance. Theory and Evidence From Java," Comparative Political Studies 49, no. 9 (2016): 1201-37. 


\section{Author Biographies}

Alexander De Juan (alexander.de-juan@uni-konstanz.de) is a professorial fellow in international administration and conflict management at the Department of Politics and Public Administration at University of Konstanz and a Senior Research Fellow at the GIGA German Institute of Global and Area Studies in Hamburg. His current research focuses on the relationship between violent conflict, state building, and development and appears in the British Journal of Political Science, Comparative Political Studies, Journal of Conflict Resolution, Political Geography and other venues. His previous work has been supported by grants from the German Research Foundation, the German Development Bank, the German Ministry for Economic Cooperation and Development, and the Gerda Henkel Foundation. In addition to academic research he regularly consults for development cooperation in fragile and conflict-affected states.

Jan Henryk Pierskalla (pierskalla.4@osu.edu) is an assistant professor of political science at The Ohio State University. His current research focuses on state building, the territorial organization of states, bureaucratic politics, and political violence. His work has been published in the American Political Science Review, Comparative Political Studies, Comparative Politics, the Journal of Conflict Resolution, and the Journal of Politics, among others. 